\title{
INSTITUTIONALIZATION PROPOSALS OF ATTENTION TO DIVERSITY AT UNIVERSITY FROM THE VISION OF LEADERS
}

\author{
Azahara Jiménez Millán, \& María García-Cano Torrico \\ Department of Education, University of Córdoba (Spain)
}

\begin{abstract}
This paper outlines a descriptive and interpretative qualitative research project that is framed within a larger study $^{1}$, the general aim of which is to diagnose university policies and practices in order to propose an Institutionalization Plan to Address Diversity in Higher Education. We have investigated the vision of university leaders as a key part of this process. To this end, 26 institutional leaders from the University of Córdoba (Spain) have been interviewed, selected intentionally in accordance with the following criteria: leadership level (Vice-Chancellor, Department Director, Dean, Director of Specific Services, President of the Student Council, Representatives of Administration and Services Staff), representation of the entire university community (Teaching and Research Staff, Students, and Administration and Services Staff), encompassing all areas of knowledge, and gender balance. Discourse analysis was used to code all the information produced - deductive and inductive -, followed by recoding and categorization, with code validation by means of intercoder agreement and expert judgment. The findings highlight existing "good practices" but also recognize difficulties. Proposals for institutionalization pertain to the following areas: management (policies and strategies, infrastructure, recognition, external entities and resources); education (awareness and sensitization, training and specific measures for students from protected groups); innovation, research and transfer, dissemination, evaluations and culture. The discourse of these leaders highlights training, awareness and dissemination as fundamental lines of action. In addition, we found certain intergroup differences between the different levels of leadership. The conclusions coincide with previous studies with regard to some of the proposals. However, in this case, a greater volume of more specific categories and subcategories is obtained. Consequently, this study contributes greater applicability and functionality to the context studied with a greater possibility for transference. Furthermore, unlike the international studies developed that focus on the body responsible for addressing or dealing with diversity, this paper takes into account all levels of organizational leadership and sectors of the community. This is important if we intend to address or manage diversity as an integral part of university life.
\end{abstract}

Keywords: Institutionalization, addressing diversity, higher education, leadership, policy development.

\section{Introduction}

University institutions are engaged in a process of complex transformation on a global scale that affects interaction between how learning processes develop, how knowledge is constructed, and how they relate to society. Specifically, we could say that they are immersed in a dilemma between two perspectives: the commercial angle that engulfs universities, according to the regulations of the World Trade Organization (Santos, 2017); and a necessary response from the perspective of social justice that offers a commitment to inclusion (Gibson, 2015).

The second of these two perspectives, which emphasizes the social responsibility of universities, involves moving away from a paradigm of exclusivity, based on the merit of a few minorities that access higher education and whose policies and measures are aimed at these groups that are already 'in', in order to achieve their continuation and achievement (Gavino, Eber \& Bell, 2010); towards a paradigm of inclusivity, whose raison revolves around the principles of democracy (Stefani \& Blessinger, 2018). Change directed towards a new organizational culture in which leaders need models with empirical evidence and tools that guide them towards new practices and realities.

This paper is part of a larger project, the general purpose of which is to diagnose key dimensions of an institutionalized approach to addressing diversity by designing a transfer plan. The first stage involved carrying out a national and international exploration of the current situation of university institutions in

${ }^{1}$ Project funded by Spain's Ministry of Economics, Industry and Competitiveness: “Attention to Diversity and Inclusive Education at University. Diagnostics and Evaluation of Institutionalization Indicators” (Ref. EDU2017-82862-R). 
relation to addressing inclusivity in their policies and the way in which it is discussed by the university community.

This study focuses particularly on one of the dimensions of institutionalizing the inclusive management of diversity in higher education: leadership, considered by the literature to be a decisive component (Adserias et al, 2016) to ensure that diversity does not remain merely a declaration of intent but instead reaches the necessary institutional culture (Kezar, 2007).

\section{Theoretical framework}

In national and international literature in the fields of education and business, the concepts of inclusion and leadership are increasingly found in conjunction. Analysis of leadership in education has been carried out chiefly by analyzing its role in the early stages of education (for example, Bolívar, López \& Murillo, 2013); however, references to research in higher education are decreasing. Hence, the demand expressed by various authors to highlight this gap in knowledge (Bryman, 2007).

In relation to the literature about the inclusive management of diversity, as argued by Shore et al. (2009), diversity has been studied from a reactive stance towards the prejudices and discrimination present in society, not obtaining positive results for people or institutions. Consequently, there is an urgent need for theoretical and empirical research that, through a more positive and proactive change of paradigm, raising new questions that are more closely linked to when and how diversity assists the success of the organization, provokes new approaches to management and promotes new opportunities.

For Manzano Arrondo (2015), the problematic situation in which university education finds itself today is rooted in growing pressure from the market in the face of the promotion of social change and the common good. Through the analysis of publications and interviews with academics and activist teachers, the author presents the difficulties faced in terms of teaching (training, availability, adaptation and anticipation of market changes), research (technology transfer to companies, competitiveness, partnerships with private organizations) and institutionally (reduction of public funding and staff, mergers between universities, business management styles). Based on these obstacles, he offers proposals to stimulate the social commitment of universities related with the promotion of an ethical university culture and partnerships with the tertiary sector.

Pérez and Sarrate (2013), on the other hand, focusing on the student collective, develop proposals to promote inclusive education from the perspective of university social responsibility in cultural diversity. These include policies and participatory action plans with values of diversity and fairness, and which pay attention to problems originating from social and cultural differences (induction programmes, adaptation and technique development courses, spaces for dialogue and mutual knowledge), teachers who are sensitive to diversity (offer of distance education to adapt to different needs and fit in with the work/life balance of students), artistic, sporting and charitable activities designed by the students, peer tutorials, methodological education resource centres, advice for training and experience exchange, financial assistance (grants, loans, exemptions, quotas and differentiated fees), didactic/methodological research and innovation that fosters the inclusion of immigrant students.

Devlin (2013), in contrast, looks at the results of two national studies in 16 Australian universities with successful workers and students from low socioeconomic backgrounds. She proposes new lines in relation to the leadership and management of the teaching and learning process for university diversity: institutional strategic alignment, reward and recognition of teaching staff, appropriate resources, and an effective support structure.

Given that the bibliography flags up the general lack of research focusing on the leadership required to implement diversity agendas and highlights the need for research to guide leaders (Adserias et al., 2016), we have decided to investigate leadership by analyzing the discourse of leaders at the highest organizational levels of the university institution. We understand that these individuals have the power to legitimize and give meaning, through their decisions, thereby generating social discourse.

These are the questions that guide the research presented here. The aim of this paper is to interpret the discourse of leaders within universities in relation to proposals to institutionalize the inclusive management of diversity with a view to ascertaining their understanding of diversity in relation to the priority areas of action for the university.

\section{Methods}

The research conducted here is developed from a qualitative perspective through the case study of a medium sized university located in Andalusia, Spain. For the purposes of this paper, we focus on analyzing the discourse of 26 institutional leaders at different levels of leadership (Vice Chancellor, Dean, Director of Department, Director of Specific Services, Head of Administration and Services Staff, and 
President of the Student Council), using a balanced sample in terms of gender and affiliation with different areas of knowledge.

The instrument used to generate data was a semi-structured interview that was recorded and subsequently transcribed. Thematic analysis was conducted by means of deductive and inductive coding, validated in accordance with intercoder agreement and using the software package Atlas.ti v.8.3. The participants were informed of the object of the study and the anonymity of the data provided, and gave their consent to participate therein.

\section{Results}

The leaders interviewed stated that they encountered certain difficulties when it came to responding from an inclusive perspective. These include:

- Lack of training. Lack of knowledge regarding how to act in certain situations, chiefly with students who have special educational needs or some kind of disability, which generates insecurity and fear.

- Lack of knowledge regarding the needs of certain collectives, especially invisibilized groups and those who do not declare their needs.

- Imposition of macro-level rules or pressures that exacerbate bureaucracy and increase work saturation.

- Overloading with information and work saturation that leads to a diagonal reading of documentation, lack of interest in events, and consequently a lack of awareness regarding issues that transcend their teaching and research tasks per se.

- Financial difficulties to transform spaces and eliminate architectural barriers.

In order to overcome these difficulties, the leaders interviewed from the different levels have made proposals that we have grouped into the following areas: management, education, research, innovation and transfer, dissemination, evaluations and culture (Table 1).

Table 1. Categories of proposals made by institutional leaders.

\begin{tabular}{|c|c|c|}
\hline & CATEGORIES & PROPOSALS \\
\hline \multirow{18}{*}{ 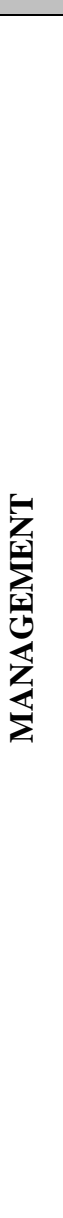 } & \multirow{7}{*}{$\begin{array}{c}\text { POLICIES AND } \\
\text { STRATEGIES }\end{array}$} & University policy as a transversal lynchpin \\
\hline & & $\begin{array}{l}\text { Universal accessibility plan, both in physical and curricular terms } \\
\text { Promote Diversity }\end{array}$ \\
\hline & & Specific policies that increase visibility \\
\hline & & $\begin{array}{l}\text { Specific programme to engage diversity in University Access } \\
\text { (SEN/Disability, Socioeconomic background) }\end{array}$ \\
\hline & & $\begin{array}{l}\text { Find mechanisms so that students from protected groups have } \\
\text { more room to grow at University and are always accepted }\end{array}$ \\
\hline & & $\begin{array}{l}\text { Retention and progress of students from protected groups using } \\
\text { less exacting grants systems }\end{array}$ \\
\hline & & Fundamental component of the education pact \\
\hline & \multirow[b]{2}{*}{ INFRASTRUCTURE } & Adaptation of buildings, eliminating architectural barriers \\
\hline & & $\begin{array}{l}\text { Design new buildings from the perspective of universal } \\
\text { accessibility }\end{array}$ \\
\hline & \multirow{5}{*}{ RECOGNITION } & $\begin{array}{l}\text { Academic and professional recognition of people who develop } \\
\text { measures for Addressing Diversity (AD) because these are } \\
\text { professional improvements that assist dissemination }\end{array}$ \\
\hline & & $\begin{array}{l}\text { Include } \mathrm{AD} \text { as an item on the Contract-Programme used to } \\
\text { evaluate Departments }\end{array}$ \\
\hline & & $\begin{array}{l}\text { Maternity leave should not count as a result in terms of scientific } \\
\text { production }\end{array}$ \\
\hline & & $\begin{array}{l}\text { Lighten the load for teachers involved in AD and/or for } \\
\text { collaboration with the Diversity Management Service (DMS) }\end{array}$ \\
\hline & & Create an AD award to increase visibility \\
\hline & $\begin{array}{l}\text { EXTERNAL } \\
\text { ENTITIES }\end{array}$ & $\begin{array}{l}\text { Establish synergies with other institutions, organizations and } \\
\text { associations of underrepresented groups and underprivileged areas } \\
\text { that contribute knowledge, experiences and resources }\end{array}$ \\
\hline & \multirow{3}{*}{ RESOURCES } & Economic and human resources \\
\hline & & $\begin{array}{l}\text { SEN Specialists that work in closer collaboration with teaching } \\
\text { and research staff }\end{array}$ \\
\hline & & Promote the DMS \\
\hline
\end{tabular}




\begin{tabular}{|c|c|c|}
\hline \multirow{11}{*}{ 㫣 } & \multirow{2}{*}{$\begin{array}{l}\text { AWARENESS AND } \\
\text { SENSITIZATION of } \\
\text { the entire university } \\
\text { community }\end{array}$} & $\begin{array}{l}\text { Campaigns with and without the collaboration of External Entities } \\
\text { that allow for reflection }\end{array}$ \\
\hline & & $\begin{array}{l}\text { Dealing with diversity as a transversal subject that permeates all } \\
\text { study plans }\end{array}$ \\
\hline & \multirow{7}{*}{ TRAINING } & $\begin{array}{l}\text { How? } \\
\text { VOLUNTARY for the whole university community } \\
\text { RECOGNITION for faculty and administration staff } \\
\text { COMPULSORY for students }\end{array}$ \\
\hline & & $\begin{array}{l}\text { Design teaching actions from the perspective of universal } \\
\text { accessibility }\end{array}$ \\
\hline & & $\begin{array}{l}\text { TRAINING on two levels: Open courses, and ensuring teacher } \\
\text { receptiveness } \\
\text { Inclusive methodological approaches that adapt to the diversity of } \\
\text { the students in all branches of knowledge (not only in the } \\
\text { discipline being taught or researched but also with regard to how) }\end{array}$ \\
\hline & & Foster reflective teaching practices \\
\hline & & $\begin{array}{l}\text { Incorporate AD contents in the masters' degree for new university } \\
\text { teachers }\end{array}$ \\
\hline & & Transversal subject that permeates all study plans \\
\hline & & Foster the advantages of technology by rolling out online subjects \\
\hline & SPECIFIC & Academic support with well-balanced assistance \\
\hline & $\begin{array}{l}\text { AT PROTECTED } \\
\text { GROUPS OF } \\
\text { STUDENTS } \\
\end{array}$ & Professional guidance \\
\hline \multirow{5}{*}{ 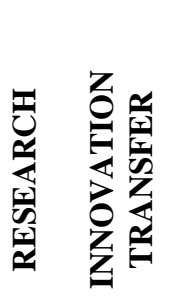 } & \multicolumn{2}{|c|}{ Encourage research in AD, ground practices in scientific evidence. } \\
\hline & \multicolumn{2}{|c|}{ Ground practice in scientific evidence } \\
\hline & \multicolumn{2}{|c|}{ Innovative initiatives in AD. } \\
\hline & \multicolumn{2}{|c|}{$\begin{array}{l}\text { Simple questionnaire with open-ended questions conducted periodically with the governing } \\
\text { teams of centres, to analyze the current situation in terms of AD. }\end{array}$} \\
\hline & \multicolumn{2}{|c|}{ Encourage agreements with external entities. } \\
\hline \multirow{5}{*}{ 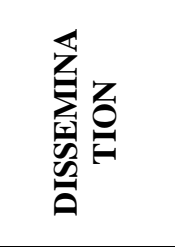 } & \multicolumn{2}{|c|}{ Give a voice and visibility to all people from protected groups and to their progress. } \\
\hline & \multicolumn{2}{|c|}{ Scientific Dissemination Office and UCO News to regularly tackle diversity. } \\
\hline & \multicolumn{2}{|c|}{ Towards society in general, and influencing the role of families. } \\
\hline & \multicolumn{2}{|c|}{ Disseminate good practices between Departments and Universities } \\
\hline & \multicolumn{2}{|c|}{ Foster the function of the Social Council. } \\
\hline
\end{tabular}

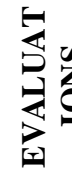

Development of evaluations of the AD measures implemented

Create continuity for the work initiated in favour of Gender Equality

Change Disability to Diversity in a broad sense that encompasses gifted students, SEN

Support, Socioeconomic background, Sexual Identity, ...

Note. Authors' own

Intra-group analysis highlights a greater concern for training, awareness and sensitization within the university community, as well as the importance of dissemination throughout this entire process. On occasions, more intra-group (leaders from the same level of management or group represented) than intergroup difference is observed, which leads us to deduce that the influence of personal experience is greater than the group represented.

In spite of all of this, we see preferences towards certain issues over others between the different levels of leadership. For example, Vice Chancellors are more likely to cite the issue of training, above the other leaders, whereas this issue is the least cited among leaders of centres (Deans). As for professional or institutional recognition, this is the most important issue for Directors of Departments, after training, but it 
is not so for those who manage at the top level, such as Vice Chancellors. As for resources, whereas this issue is proposed by Vice Chancellors, Deans, Directors of Departments and Specific Services, it is not seen to be a priority for students and administration and services staff.

\section{Conclusions}

For the development of inclusion policies, the role played by the highest tier of university leaders is a priority. Hence the importance of knowing their perceptions as well as the difficulties encountered and their proposals, in order to create a more inclusive university life, because this is not a parallel charitable activity; rather it is part of its main function. Therefore, universities have the responsibility not to spare any expense or effort to ensure that the inclusive management of diversity becomes part of the institutional culture.

Commitment to inclusive higher education supports a diversity agenda that should not be present on paper only, but rather one that deploys a whole raft of measures. In this respect, our results coincide partly with the contributions made by authors such as Pérez and Sarrate (2013), focusing on student cultural diversity, Devlin (2013), who presents success stories in diversity according to socioeconomic background, and Manzano Arrondo (2015), who looks at establishing links with the tertiary sector. However, in this case, by focusing for the first time on transversal leadership, in other words, all levels of leadership with an institution, we have obtained specific proposals that could contribute greater applicability and functionality to the study developed, with a greater possibility for transfer.

\section{References}

Adserias, R. P., Charleston, L. J., \& Jackson, J. F. (2016). What style of leadership is best suited to direct organizational change to fuel institutional diversity in higher education? Race Ethnicity and Education, 20(3), 315-331. doi: 10.1080/13613324.2016.1260233

Bolívar, A., López, J. \& Murillo, F. J. (2013). Liderazgo en las instituciones educativas. Una revisión de líneas de investigación. Revista Fuentes, 14, 15-60.

Bryman, A. (2007). Effective leadership in higher education: a literature review. Studies in Higher Education, 32, 693-710, doi: 10.1080/0307507070168511

Devlin, M. (2013.) Effective University Leadership and Management of Learning and Teaching in a Widening Participation Context: Findings from two national Australian studies. Tertiary Education and Management, 19(3), 233-245, DOI: 10.1080/13583883.2013.793380

Gavino, M. C., Eber, J. E., \& Bell, D. (2010). Celebrating our diversity: creating an inclusive climate in a US university. Equality. Diversity and Inclusion: An International Journal, 29(4), 395-405.

Gibson, S. (2015). When rights are not enough: What is? Moving towards new pedagogy for inclusive education within UK universities. International Journal of Inclusive Education, 19 (8), 875-886. doi: 10.1080/13603116.2015.1015177

Kezar, A. J. (2007). Tools for a time and place: Phased leadership strategies to institutionalize a diversity agenda. The Review of Higher Education, 30(4), 413-439. doi:10.1353/rhe.2007.0025

Manzano-Arrondo, V. (2015). Activismo frente a norma: ¿quién salva a la universidad? RIDAS. Revista Iberoamericana de Aprendizaje Servicio, (1), 28-55. doi: 10.1344/RIDAS2015.1.3

Iverson, S. V. 2008. "Capitalizing on Change: The Discursive Framing of Diversity in U.S. Land-Grant Universities." Equity \& Excellence in Education 41 (2): 182-199. doi: 10.1080/10665680801972849

Pérez, G., \& Sarrate, M. L. (2013). Diversidad cultural y ciudadanía. Hacia una educación superior inclusiva. Educación XX1, 16(1).

Santos, B.S. (2017). Justicia entre Saberes: Epistemologías del Sur contra el epistemicidio. España: Morata

Shore, L. M., Chung-Herrera, B. G., Dean, M. A., Ehrhart, K. H., Jung, D. I., Randel, A. E., \& Singh, G. (2009). Diversity in organizations: where are we now and where are we going? Human resource management review, 19(2), 117-133.

Stefani, L., \& Blessinger, P. (2018). Inclusive Leadership in Higher Education. Oxford: Taylor \& Francis Group Ltd. 